УДК 231.01

DOI 10.35423/2078-8142.2019.5-6.11

Ф. В. Стрижсачук, кандидат філософських наук, дочент, старший науковий співробітник Центру дослідження релігії, Національний педагогічний університет імені М. П. Драгоманова м. Київ, Украӥна e-mail: tedandgalina@gmail.com ORCID: https://orcid.org/0000-0002-3644-9382

\title{
ТРИНІТАРНА ЕКЛЕЗІОЛОГІЯ МИРОСЛАВА ВОЛЬФА
}

Відродження доктрини про Трійцю у ХХ ст. позначилося на всіх сферах християнського богослов'я і практики. Вчення про иеркву також не залишилося поза впливом сучасного тринітарного богослов'я. Еклезіологія Мирослава Вольфа є яскравим прикладом інтеграиії тринітарного богослов'я у вчення про иеркву з перспективи незалежних євангельських иерков. Вольф відштовхується від концепиії першого баптиста Джона Сміта про те, щчо цеерква - иее спільнота людей, зібраних в ім'я Христа. Тринітарну складову своєї еклезіології Вольф розвиває в діалозі з двома видними представниками римо-католицької та православної еклезіологї: Йозефом Ратиингером і Іоанном Зізіуласом. Проводячи аналогію між Трійцею і иерквою єдність Трійці Вольф вбачає не в єдиній сутності Бога і не в Особі Отия, а скоріше в перихоретичній єдності божественних Осіб. Так само иерква має полічентричний характер, іï єдність створюється людьми, наділеними дарами Святого Духу.

Ключові слова: доктрина про Трійцю, еклезіологія, церква, Мирослав Вольф, незалежні євангельські церкви, перихореса.

Ренесанс доктрини про Трійцю в сучасному християнському богослов'ї спричиняє відчутний вплив на інші частини богослов'я. Тепер доктрина про Трійцю не розглядається як окремий ізольований розділ систематичного богослов'я. 3'являється дедалі більше голосів за те, щоб переглянути «всю мережу християнської докт-

(C) Стрижачук Ф. В., 2019 
рини 3 тринітарної перспективи» [6, с. 10]. Доктрині про Трійцю приписується методологічна функція для розвитку класичних доктринальних тем. Вчення про творіння, богословська антропологія, доктрина про особу та діло Христа, есхатологія, богослов'я релігій та ін. досліджуються зараз з перспективи доктрини про Трійцю. Із цієї причині не стало несподіванкою, що богослови усвідомили, що доктрина про Трійцю може бути застосована у розвитку вчення про церкву.

Останніми роками тривають дискусії про роль тринітарного богослов'я у вченні про церкву. Серед досліджень богословів, які зробили внесок у цю дискусію, вирізняється монографія Мирослава Вольфа «За нашою подобою: Церква як образ Трійці» [1]. У цій книзі автор робить спробу розвинути еклезіологію євангельських незалежних церков, яка виходить за межі індивідуалізму. Вольф розвиває свою еклезіологію в критичному діалозі 3 римокатолицькою і православною еклезіологіями. Він говорить: «Мета моїх зусиль - екуменічна еклезіологія, не в сенсі конструкції, яка посилається на всі традиції і не вкорінена ні в одній, але в сенсі, що всі великі теми безсумнівно протестантської еклезіологічної мелодії збагачені католицькими і православними голосами» $[7$, c. $x i]$.

Церква - спільнота людей. У побудові еклезіології Мирослав Вольф не робить своїм єдиним відправним пунктом доктрину про Трійцю. Порушуючи питання «Що таке церква?», Вольф починає 3 людей. Він посилається на вислів, який використовувався людьми Східної Німеччини, коли вони руйнували Берлінську стіну в 1989 р. Вони говорили: «Народ - це ми!». Вольф вважає, що християни також повинні сказати «Церква - це ми!» [1, с. 165]. Це твердження підкреслює, що церква - це не теорія і не ідеал, вона $\epsilon$ історичною реальністю. Церква існує в певний час і в конкретному місці. Церква - це спільнота, яка складається з особистостей, вона не є єдиним колективним суб'єктом. Церква - це зібрання людей, які зібралися в ім'я Христа. Вольф відкидає ідею, що церква $є$ «суб'єктом», невидимою сутністю, окремою від конкретних історично-обумовлених зібрань людей, які відповіли на євангельську проповідь [2, с. 115]. У концепції церкви у Вольфа важливими $є$ 
два елемента: люди та їх вільне рішення вступити в общину віри в ім'я Христа. Проте, відповідь людини на проповідь Свангелії сама по собі не створює церкву. Церква не є вільною асоціацією, творінням людини. Таке розуміння церкви Вольф називає «волюнтаристським спотворенням віри». Церква створюється Духом Святим, який приводить людей до віри в Христа і вводить у спілкування церкви. Христос живе в цих відносинах людей, і саме ця присутність Христа за посередництвом Святого Духу створює церкву.

Ці дві основні ознаки церкви - зібрання людей і віру в Христа - Вольф, слідуючи за першим баптистом Джоном Смітом, знаходить у біблійному тексті Матвія 18:20: «Бо де двоє чи троє в Ім'я Моє зібрані, там Я серед них». Цей тест був завжди популярний серед віруючих незалежних євангельських церков. Цей текст також $\epsilon$ ключовим для Вольфа [7, с. 136]. Суть церкви не має нічого спільного з будівлями, епіскопами, священиками, проповідниками чи парафіяльними округами. Церква - це першою чергою спільнота людей, які поклоняються Богу. Церква - це зібрання віруючих людей, які зійшлися разом у будь-який час і в будь-якому місці в ім'я Ісуса Христа. Отже, «Церква $є$ церквою Ісуса Христа... або вона не $\epsilon$ церквою взагалі» [7, с. 146]. Вислів «в ім'я Ісуса Христа» означає, що метою зібрання є поклоніння Христу як Спасителю, свідчення про Нього, сповідання віри у Нього як їх Господа і Господа усього світу. Церква як зібрання віруючих в ім'я Христа передбачає віру та відданість тих, хто зібралися разом. Усюди, де є такі зібрання, ми зустрічаємося з церквою у повному розумінні цього слова, вважає Вольф. У такий спосіб він вкорінює свою еклезіологічну думку в традиції незалежних євангельських церков, 3 типовим для них наголосом на особистому рішенні приєднатися до спільноти віруючих [3, с. 315]. Вольф усвідомлює, що Христос не обіцяв Своєї присутності окремому індивіду поза зібранням віруючих, така обіцянка відноситься першою чергою до спільноти християн. Таким чином, відношення між Христом і віруючим опосередковано церквою. Це стає очевидним, коли йдеться про священнодійства. Ніхто не може здійснювати таїнства сам по відношенню до себе. Тут Вольф критикує рішення Джона Сміта охрестити себе самостійно, $\mathrm{i}$ називає його «невдалим» [7, с. 153]. Тоді як приймати священнодії 142

Institute of Philosophy of H. S. Skovoroda of NAS of Ukraine 
слід особисто. Проте Вольф зауважує, що здійснення священнодій церквою не означає, що церква володіє і обдаровує сотеріологічною благодаттю. Разом з Лютером і Кальвіном Вольф твердить, що прийняттю священнодій має передувати віра. Він говорить: «Немає церкви без священнодій, але немає священнодій без віри» [7, с. 154]. Віра окремого віруючого залишається важливою підвалиною для церкви. Віна не є людською активністю чи надбанням, вона є Божим даром через Духа. Бог є єдиним, хто дає віру і спасає, цього не робить церква. Хоча віруючий отримує віру в церкві, він не отримує ії від церкви. Щодо цього Мирослав Вольф міцно тримається протестантської традиції. Проте, він намагається підвести традицію незалежних євангельських церков до зустрічі з еклезіологічними ученнями римо-католицької та православної церков. Він глибоко переконаний, що сучасні християни усіх конфесійних традицій стикаються 3 ментальністю споживача, де часто-густо релігію чи церкву сприймають як «склад» релігійних послуг. Від цих сучасних тенденцій до консюмеризму та індивідуалізму, які стають рисами сучасної християнської церкви, Мирослав Вольф шукає «ліки» в еклезіології, яка грунтується на доктрині про Трійцю [8, с. 744]. Доктрина про Трійцю є для нього моделлю або дзеркалом для церкви.

Церква як образ Трійці. Коли Мирослав Вольф починає розглядати тему відношення між доктриною про Трійцю і вченням про церкву, він зауважує: «Сьогодні, теза про те, що церковна спільнота повинна бути відображенням тринітарної спільноти, має практично статус самоочевидного твердження» [7, с. 191]. Відзначивши цей широкий консенсус 3 цього питання, він висловлює здивування, що ця кореляція між Трійцею та церквою все ще недостатньо вивчена, і ставить собі за мету заповнити цю лакуну. Хоча Вольф не є першим [4], хто вивчає це питання, проте його підхід вирізняється тим, що він ретельно аналізує можливості та обмеження аналогії між Трійцею і церквою.

Для обгрунтування можливості такої аналогії та іiї легітимації Вольф наводить три аргументи. По-перше, з часів Парменіда західна філософія характеризується діалектикою протиставлення одного і множинності - дихотомією між єдністю і плюралізмом. У 
нашому мисленні про Бога, людство, світ і також про церкву, ії єдність та різноманітність нам слід встановити коректний баланс. Він говорить: «мислити послідовно в тринітарних термінах означає уникнути цієї дихотомії» [7, с. 193]. Триєдиний Бог є основою як єдності так і різноманітності. По-друге, входження в християнську церкву відбувається через хрещення, яке за визначенням є тринітарною подією. Через хрещення віруючий вводиться в обидві спільноти: тринітарну і еклезіологічну. Таким чином, якщо християнська ініціація є тринітарною за своєю природою, то Трійцю слід розглядати як основну детермінанту церкви [3, с. 316]. Вольф обгрунтовує цю тезу, звертаючись першою чергою до Матвія 28, де Ісус дає настанову апостолам хрестити народи в ім'я Отця, Сина і Святого Духа, а також до тріадичних текстів Нового Завіту, в яких божественна спільнота співвідноситься з спільнотою віруючих (Івана 17:21; 1 Коринтян 12:4-6; Ефесян 4:4-6). Спілкування церкви 3 триєдиним Богом означає щось більше, ніж формальне співвіднесення. Відносини між віруючими в церкві повинні відображати взаємну любов та рівноправні відносини божественних Осіб. По-третє, Вольф звертається до християнської традиції, де знаходить приклади використання доктрини про Трійцю як моделі для еклезіологіï. Уже Оріген наполягав, що церква сповнена Святою Трійцею. А Кипріян описував церкву як людей, об'єднаних в одне в єдності Отця, Сина і Святого Духу [7, с. 195-196].

Водночас, Вольф є досить чутливий до обмежень аналогії між Трійцею і церквою. Він робить два важливих застереження. По-перше, разом з Еріком Петерсоном, він вважає, що таємницю Трійці слід шукати в Богові, а не у творінні [6, с. 105]. Богослов’я та антропологія не можуть бути зведені одне до одного. Проте, Божою метою для творіння $є$ поселення триєдиного Бога у створеному світі. Це дає можливість трансформувати тринітарні ідеї в еклезіологічні. І хоча не слід говорити про повну ідентичність між Трійцею та церквою, але безперечно аналогія між ними існує. Подруге, не слід забувати про відмінність, яка існує між недосконалою історичною церквою та іiі есхатологічним майбутнім. Таким чином, крім онтологічного обмеження існує також есхатологічне обмеження. Церква ще знаходиться на своєму шляху до есхатологічної мети, і тому їі відповідність до досконалої спільноти Трійці 144

Institute of Philosophy of H. S. Skovoroda of NAS of Ukraine 
$\epsilon$ ще недосконалою. Проте, залишається «еклезіологічно релевантне питання про те, як церква корелюється з Трійцею в ході історії» [7, c. 200].

Діалог про церкву з Й. Ратцінгером та І. Зізіуласом. Після обгрунтування можливості аналогії між Трійцею та церквою та обговорення обмежень цієї аналогії, виникає питання: про який саме устрій церкви йдеться? А також до якої церви ми прийдемо, коли спробуємо послідовно провести аналогію між життям триєдиного Бога і церквою? На цьому етапі Мирослав Вольф вступає в дискусію 3 двома авторитетними представниками римокатолицької і православної церков: Йозефом Ратцінгером (1927-) та Іоанном Зізіуласом (1931-). У своєму дослідженні Вольф аналізує, в який спосіб у богословських працях обох богословів доктрина про Трійцю відноситься до їх вчення про церкву.

Йозеф Ратцінгер розглядає єдність та тріадичність Бога як рівно важливі (equiprimal) аспекти доктрини про Трійцю. Проте, його тринітарне богослов'я починається з божественної єдності. Ратцінгер розглядає Особи Отця, Сина і Святого Духа як відносини, які перебувають у фундаментальній субстанційній єдності. У подібний спосіб в його еклезіології єдина вселенська церква є конститутивною для багатьох помісних церков. Спілкування між помісними церквами є подібним на перехоретичну спільноту божественних Осіб у Трійці, які знаходяться в інтенсивному взаємному спілкуванні. Проте, помісні церкви можуть існувати лише завдяки вселенській церкві, якою є церква у Римі. За тлумаченням Вольфа, «Помісні церкви $є$ церквами саме у відношенні до цілого» [7, с. 201]. В обох випадках, Трійці і церкви - єдність обгрунтовує та підтримує множинність. Слідуючи магістральній лінії тринітарного богослов'я Заходу, Ратцінгер вважає, що Особи Трійці збігаються 3 внутрішніми тринітарними відносинами, і як відносини вони не мають онтологічного субстрату. Триєдиний Бог поза Трійцею діє по відношенню до створеного світу як єдиний суб'єкт (opera ad extra in divisa sunt). Вольф вважає, що трансляція цієї тринітарної реальності, як їі розуміє Ратцінгером, в еклезіологічні категорії означає, що єдина вселенська церква домінує і певною мірою навіть поглинає помісні церкви. 
Вольф також не погоджується з Ратцінгером і з усією католицькою традицією, яка починається з Томи Аквінського, що особа - це «чисте відношення». Таке розуміння особи редукує Особи Трійці до відносин у середині єдиної божественної сутності: Отець стає «отцівством», Син - «синівством» і Дух Святий - «ісходженням». Особи, зведені до рівня чистих відносин, не можуть діяти. Вольф тут погоджується з Кетрін ЛаКугна в тому, що таке розуміння божественних Осіб, в якому триєдиний Бог взаємодіє зі світом як одна особа або один суб'єкт - $є$ «провалом» західного вчення про Трійцю [5, с. 145]. Вольф наполягає на тому, що Особи Трійці слід розглядати як «Суб’ єкти». У цьому відношенні Вольф погоджується з Мольтманом в тому, що особа і відносини доповнюють одне одного. У тринітарному житті ідентичність божественних Осіб взаємно зумовлюється через їх відносини [2, с. 115116]. Бог Отець є Отцем Сина і посилаючим Духа, Син є народженим від Отця, Дух Святий походить від Отця тощо. Особи знаходяться в постійних взаємних відносинах.

У подібний спосіб і в церкві окрема особа віруючого виникає разом з громадою. Ні церква, ні особа не передують одна одній. Вольф говорить: «Так само, як божественні іпостасі, члени церкви не можуть жити один без одного; кожен християнин формується як віруюча людина через свої взаємовідносини з іншими християнами, при цьому природа їх церковної особистості являє себе в тому, що вони одночасно відають і отримують» [1, с. 258].

Подібно до Мольтмана, Мирослав Вольф вбачає чітке розмежування між західною і східною доктриною про Трійцю. Іоанн Зізіулас є для нього типовим представником східного підходу. Згідно 3 переконанням Зізіуласа, рефлексії про Святу Трійцю мають починатися з аналізу концепції «особи», як це можна побачити ще у каппадокійських отців. Три божественні Особи разом конституюють одного триєдиного Бога. Сдина божественна сутність не має онтологічного пріоритету перед тринітарними Особами. Скоріше навпаки, оскільки божественна сутність існує лише як єдність Осіб, реальне буття Бога не є чимось, що знаходиться поза Отцем, Сином і Духом Святим. Буття Бога полягає саме у взаємному спілкуванні тринітарних Осіб. Проте Зізіулас не вважає, що три божественні Особи мають абсолютно однаковий онтологічний статус. 146

Institute of Philosophy of H. S. Skovoroda of NAS of Ukraine 
Він приписує онтологічний пріоритет Особі Отця. Бог Отець у Зізіуласа вважається arhe або причиною божественного буття, джерелом Трійці [11, с. 51-52]. Для еклезіології це має наступні наслідки. По-перше, поза множиною помісних церков немає ніякої додаткової реальності у вигляді вселенської церкви. Навпаки, самі помісні церкви конституюють вселенську церкву. Кожна помісна церква $\epsilon$ вселенською церквою в певному місці. По-друге, передумовою того, що помісна церква $є$ екземпліфікацією вселенської церкви, є відкритість помісної церкви до еклезіологічного спілкування 3 іншими помісними церквами, тому що неможливо представляти вселенську церкву наодинці, в ізоляції. По-третє, особа єпископа має особливу позицію в церкві, тому що він віддзеркалює у церкві Особу Отця, який є arhe триєдиного Бога. Хоча Зізіулас намагається уникати будь-яких «пірамідальних концепцій» в еклезіології, водночас він легітимізує ієрархічну структуру в церкві, проголосивши авторитет єпископа над общиною [9, с. 183]. Хоча єпископ є «зумовленим» громадою, так само, як Бог Отець у певному сенсі «зумовлений» Сином, він конституює громаду. Зізіулас говорить: «Одиничність єпископа у помісній церкві є sinequanon умовою для кафолічності церкви» [10, с. 30-31].

Мирослав Вольф погоджується із Зізіуласом щодо другого положення, але має іншу думку відносно першого і третього положення. Вольф відкидає ідею вищості особи єпископа, тому що рівність усіх віруючих є відображенням рівності тринітарних Осіб. Він погоджується із Зізіуласом, що, шукаючи відповідність між Трійцею та церквою, не слід брати за відправний пункт відношення між божественною природою і тринітарними Особами. Якщо кожна помісна церква $є$ ідентичною з єдиною вселенською церквою і якщо вселенська церква відповідає божественній природі, то кожна божественна Особа $є$ ідентичною з божественною природою. Таким чином, Вольф разом з Мольтманом і Панненбергом апелює до перихоретичної єдності Трійці. Отець, Син і Дух Святий взаємно проникають один в одного і поселяються один в одному, але при цьому тринітарні Особи не перестають бути відмінними один від одного [7, с. 209]. Вольф переконаний, що відображення цієї тринітарної реальності слід шукати у близьких стосунках і взаємності, які існують між помісними церквами. 
Однак Мирослав Вольф не забуває нагадати про свої застереження. По-перше, у строгому сенсі, не може бути абсолютної відповідності між перихоретичною єдністю Трійці і еклезіологічною єдністю, тому що людські суб'єкти мають, скоріше, зовнішні відносини, а не внутрішні. Крім цього, якщо Трійця $є$ досконалою спільнотою в любові, то церковна спільнота ще очікує свого есхатологічного оформлення і тому є недосконалою. Церковна спільнота лише в есхатоні повною мірою братиме участь в єдності Трійці. Поки ще церква знаходиться на шляху до есхатологічного оформлення, вона $є$ не лише спільнотою любові, а також спільнотою волі. Це означає, що церкві слід мати завіт про взаємні права і відносити. Вольф також критикує Зізіуласа за «надмірно реалізовану есхатологію», яка ігнорує теперішню земну реальність гріха та недосконалості [7, с. 201].

Зробивши це застереження, Мирослав Вольф погоджується із Зізіуласом у тому, що внутрішні тринітарні відносини мають формувати еклезіологічні відносини вже зараз, а не лише в есхатологічному майбутньому. Конструюючи цю аналогію, Вольф починає з відносин між членами окремої церкви. Лише коли окремі віруючі причетні Духу Святому, який присутній і діє в общині, ця община може відповідати реальності Трійці. Вольф говорить: «Єдність церкви обгрунтована в інтеріоризації Духа в християнах» [7, с. 213]. Перихореса як взаємне проникнення та оселення тринітарних Осіб один в одному також $є$ релевантною для міжцерковних відносин. Подібно до того, як божественні Особи мають відміні характеристики, різні церкви мають свої риси, які дають можливість їх ідентифікувати. Міжцерковне спілкування за зразком перихоретичного спілкування тринітарних Осіб може їх взаємно збагатити. Якщо Трійця є спільнотою, яка відкрита до інших, різні церкви не повинні жити відокремленими та ізольованими одна від одної. Вольф заявляє: «Я пропоную практику відкритості кожної церкви по відношенню до всіх інших церков як неодмінну умову церковності» [7, с. 156]. Ідентичність помісних церков зумовлюється їх відносинами $з$ іншими церквами так само, як ідентичність Сина зумовлюється Його відносинами з Отцем і Духом; ідентичність Отця - 3 Сином і Духом, Духа - з Отцем і Сином, відповідно. Із тринітарної точки зору помісні церкви не можуть бути закритими системами 148

Institute of Philosophy of H. S. Skovoroda of NAS of Ukraine 
по відношенню одна до одної, навпаки, вони є кафолічними тією мірою, якою вони відкриті одна до одної. У такий спосіб Вольф намагається збагатити свою традицію незалежних євангельських церков, звернувшись до тринітарного богослов'я.

Із паралелізму церкви до тринітарної спільноти Вольф виводить три принципи. По-перше, церква не є єдиним суб'єктом, а, скоріше, спільнотою взаємозалежних суб'єктів. По-друге, прийняття сотеріологічної благодаті здійснюється не лише через служителів церкви, а через усіх членів церкви. По-третє, церква створюється Святим Духом, коли християни разом сповідують свою віру і проповідують слово Боже один одному, а не при посередництві офіційних церковних служінь [1, с. 282]. Грунтуючись на цих принципах, Вольф робить висновок, що церква має поліцентричний характер.

Поліцентрична церква проявляє себе через харизматичну структуру, яку Вольф тлумачить за допомогою концепції про священство всіх віруючих. Оскільки духовними дарами наділені всі віруючі і всі покликані до служіння, Христос діє у всіх членах церкви, а не лише через офіційних служителів [2, с. 288]. Поліцентрична церква вибудовується дарами Святого Духа. Христос присутній у всіх церкві і всі відповідальні за життя церкви. Такий устрій церкви передбачає взаємну субординацію членів церкви один одному за прикладом тринітарного життя Бога. Будь-яке служіння має бути локалізовано в контекст взаємної субординації та взаємозалежності. Сама ж харизматична природа церкви визначається Духом Божим, який наділяє іiі дарами. Окресливши параметри еклезіологічної спільноти, яку веде Дух Святий, Вольф доходить висновку, що концепція незалежної євангельської церкви втілює найбільш послідовно образ церкви, який відповідає образу Трійці.

Отже, ренесанс доктрини про Трійцю у XX-му столітті є помітним явищем в історії християнського богослов'я. Його вплив позначився на всіх сферах християнського богослов'я і церковної життя. Вчення про церкву також не залишилося поза сферою впливу відродження та процвітання тринітарного богослов'я сучасності. Еклезіологія євангельського богослова Мирослава Вольфа є яскравим прикладом інтеграції доктрини про Трійцю у вчення про церкву з перспективи еклезіології незалежних євангельських цер- 
ков. Вольф закладає основи еклезіології, грунтуючись на концепції першого баптиста Джона Сміта про те, що церква - це спільнота віруючих людей, які зібралися в ім'я Ісуса Христа. Тринітарну основу своєї еклезіології Вольф розвиває в діалозі та полеміці $з$ двома видними теологами римо-католицької та православної еклезіології: Йозефом Ратцінгером і Іоанном Зізіуласом. Ратцінгер закладає в основу єдності Трійці єдність божественної сутності і екстраполює цю концепцію на церкву і вбачає єдність церкви в єдності вселенської церкви в Римі. Зізіулас, своєю чергою, вважає, що єдність Трійці обгрунтовується Особою Бога Отця, і в церкві об'єднуючим фактором є особа єпископа в євхаристичній спільноті. Мирослав Вольф обирає і обгрунтовує іншу стратегію, проводячи аналогію між Трійцею і церквою він вбачає єдність Трійці не в єдиній сутності Бога і не в Особі Отця, а в перихоретичній єдності божественних Осіб. У такий самий спосіб церква має поліцентричний характер, іiі єдність створюється віруючими людьми, наділеними дарами Святого Духу.

\section{ЛITEPATУРA}

1. Вольф М. По подобию Нашему: Церковь как образ Троицы / М. Вольф. Черкассы : Коллоквиум, 2012. 424 с.

2. Стрижачук Ф. Влияние Тринитарного богословия на учение о Церкви. Богословские Размышления: Спецвыпуск, 2014. С. 107-123.

3. Brink G. van den Trinitarian Ecclesiology and the Search for Unity. A Reformed Reading of Miroslav Volf Leiden-Boston : Brill, 2009. P. 313325.

4. Gunton C. The Church on Earth: The Roots of Community Edinburgh : T \& T Clark, 1989. 48-80 p.

5. LaCugna C. M. God for us: The Trinity and Christian life / C.M. LaCugna, 1st ed. San Francisco : HarperSanFrancisco, 1991. 434 p.

6. Peterson E. Der Monotheismus als politisches Problem. Ein Beitrag zur Geschichte der politischen Theologie im Imperium Romanum / E. Peterson, Leipzig : Hegner, 1935. 234 p.

7. Volf M. After our likeness: the church as the image of the trinity / M. Volf, Grand Rapids, Mich : William B. Eerdmans, 1998. 314 p.

8. Watson N. K. Review of After Our Likeness: The Church as the Image of the Trinity. Anglican Theological Review. 1999. № 4 (81). C. 744-745. 
9. Zizioulas J. Being as communion: studies in personhood and the church / J. Zizioulas. Crestwood, N.Y : St. Vladimir's Seminary Press, 1985. 269 p.

10. Zizioulas J. The Bishop in the Theological Doctrine of the Orthodox Church. Kanon. 1985. № 7. P. 30-31.

11. Zizioulas J. D. The Doctrine of the Holy Trinity: The Significance of the Cappadocian Contribution Edinburgh: T. \& T. Clark, 1995. 44-60 p.

\section{REFERENCES}

Wolf, M. (2012). In Our Own Image: Church as the Image of Trinity. Cherkassy: Kollokvium, 424. [In Russian].

Strizhachuk, F. (2014). Influence of Trinitarian Theology on Church's Doctrine. Theological Reflections: Special Edition, 107-123. [In Russian].

Brink, G. (2009). van den Trinitarian Ecclesiology and the Search for Unity. A Reformed Reading of Miroslav Volf Leiden-Boston: Brill, 313-325.

Gunton, C. (1989). The Church on Earth: The Roots of Community Edinburgh: T \& T Clark, 48-80.

LaCugna, C. M. (1991). God for us: The Trinity and Christian life. San Francisco: Harper San Francisco, 434.

Peterson, E. (1935). Der Monotheismus als politisches Problem. Ein Beitrag zur Geschichte der politischen Theologie im Imperium Romanum. Leipzig: Hegner, 234.

Volf, M. (1998). After our likeness: the church as the image of the trinity. Grand Rapids, Mich: William B. Eerdmans, 314.

Watson, N. K. (1999). Review of After Our Likeness: The Church as the Image of the Trinity. Anglican Theological Review, № 4 (81), 744-745.

Zizioulas, J. (1985). Being as communion: studies in personhood and the church. Crestwood, N.Y: St. Vladimir’s Seminary Press, 269.

Zizioulas, J. (1985). The Bishop in the Theological Doctrine of the Orthodox Church. Kanon, № 7, 30-31.

Zizioulas, J. D. (1995). The Doctrine of the Holy Trinity: The Significance of the Cappadocian Contribution Edinburgh: T. \& T. Clark, 44-60. 


\title{
Fedir Strizhachuk
}

Candidate of Philosophical Sciences (Ph.D.), Associate Professor, Senior Fellow at the Center for the Study of Religion, M. P. Dragomanov National Pedagogical University Kyiv, Ukraine e-mail: tedandgalina@gmail.com

ORCID: https://orcid.org/0000-0002-3644-938213

\section{Trinitarian Ecclesiology of Miroslav Volf}

\begin{abstract}
The revival of the doctrine of the Trinity in the 20th century affected all areas of Christian theology and practice. The doctrine of the church also did not remain without the influence of modern Trinitarian theology. The ecclesiology of Miroslav Volf is a vivid example of the integration of Trinitarian theology into the doctrine of the church for the prospect of independent evangelical churches. Volf builds on the concept of the first Baptist John Smith that the church is a community of people gathered in the name of Christ. Volf develops the Trinitarian component of his ecclesiology in dialogue with two prominent representatives of Roman Catholic and Orthodox ecclesiology: Joseph Ratzinger and John Zizioulas. Drawing an analogy between the Trinity and the church, Volf sees the unity of the Trinity not in the single essence of God and not in the person of the Father, but rather in the re-unity of the unity of divine Persons. The church also has a polycentric character; its unity is created by people endowed with the gifts of the Holy Spirit. The renaissance of the doctrine of the Trinity in the twentieth century is a prominent phenomenon in the history of Christian theology. His influence has affected all areas of Christian theology and church life. The doctrine of the church also did not remain outside the sphere of influence of the revival and prosperity of the Trinitarian theology of the present. The ecclesiology of evangelical theologian Miroslav Wolf is a prime example of integrating the doctrine of the Trinity into the doctrine of the church from the perspective of ecclesiology of independent evangelical churches. Wolf laid the foundations of ecclesiology based on the concept of first baptist John Smith that the church was a community of believers who came together in the name of Jesus Christ. Wolf develops the trinitarian basis of his ecclesiology in dialogue and polemics with two prominent theologians of Roman Catholic and Orthodox ecclesiology: Joseph Ratzinger and John Ziziulas. Ratzinger lays the foundation for the unity of the Trinity on the unity of
\end{abstract}


the divine essence and extrapolates this conception to the church and sees the unity of the church in the unity of the universal church in Rome. Ziziulas, for his part, believes that the unity of the Trinity is justified by the Person of God the Father, and in the church the unifying factor is the identity of the bishop in the Eucharistic community. Miroslav Wolf chooses and justifies another strategy, drawing an analogy between the Trinity and the church, he sees the unity of the Trinity not in the one essence of God and not in the Person of the Father, but in the perichoretic unity of divine Persons. In the same way, the church is polycentric in nature, its unity being created by believing people endowed with the gifts of the Holy Spirit.

Keywords: doctrine of the Trinity, ecclesiology, church, Miroslav Volf, independent evangelical churches, perichoresis. 